\title{
Gonococcal urethral stricture and watering-can perineum
}

\author{
A. O. OSOBA AND O. ALAUSA \\ From the Special Treatment Clinic and Venereal Diseases and Treponematosis Research Laboratories, \\ Department of Medical Microbiology, University College Hospital, Ibadan, Nigeria
}

\section{Summary}

A total of sixteen patients with urethral stricture and/or perineal urinary fistulae (watering-can perineum) complicating gonorrhoea were seen at the Special Treatment Clinic, University College Hospital, Ibadan, Nigeria. The patients were aged between 25 and 80 years, and the latent period between the time of original attack of gonococcal infection and the development of complications varied from 4 to 50 years. The rate of divorce or marital separation is high among these patients with late sequelae of gonorrhoea.

The factors responsible for the present higher incidence of early and late complications of gonorrhoea among patients in Nigeria and other tropical countries compared with their counterparts in Europe and North American include:

(a) Lack of medical facilities in most rural areas;

(b) Inadequate treatment of venereal diseases, including the urban areas where self-medication is practised on a large scale by the general population;

(c) Illiteracy and ignorance of venereal diseases.

The cases of watering-can perineum reported here, and the subsequent chronic pyelonephritis and hypertension, reinforce the plea for early and energetic treatment of acute gonorrhoea in Africa as well as large-scale control measures by the health authorities.

\section{Introduction}

The incidence of gonorrhoea is high in Nigeria (Osoba, 1972) and it is rising as in many other parts of the world (Guthe and Idsøe, 1968; Guthe, 1972; Willcox, 1972). In developed countries, where there are adequate facilities for medical care, the course of gonorrhoea tends to be mild and complications are few. On the other hand, the severe sequelae of gonococcal infection with complications leading to infertility and sterility in both sexes (Osoba, Onifade, and Alausa, 1975) and urethral stricture with or without perineal fistulae in the male still constitute a serious medical problem in many parts of tropical Africa, particularly in the rural areas where gonorrhoea is considered to be endemic (WHO, 1974). This is due partly to lack of medical care in most rural areas and inadequate medical and diagnostic facilities in the urban areas, and partly to illiteracy and ignorance of the consequences of venereal diseases. The treatment of venereal diseases is usually left to herbalists in rural areas and to the individual by means of self-medication with antimicrobial agents obtained directly from the chemists shop in urban areas (Alausa, Osoba, and Sogbetun, 1975). The result is that many patients with sexually transmitted diseases in tropical Africa are either improperly or inadequately treated in the early stages of infection and complications are therefore common.

The occurrence of urethral stricture and perineal fistulae (watering-can perineum) complicating gonorrhoea would eventually force the patient to seek proper medical treatment, which is only available at present in few centres in Nigeria. The social embarrassment from the characteristic urinary odour accompanying perineal fistulae is perhaps one of the main factors leading to medical consultation at the hospital. The purpose of this paper is to report our experience of the clinical features of urethral stricture and watering-can perineum complicating inadequately treated gonorrhoea among male Nigerian patients and to draw the attention of physicians, particularly in the developing countries, to these devastating lesions due to the gonococcus.

\section{Material and methods}

Sixteen consecutive male patients aged between 25 and 80 years with a clinical diagnosis of urethral stricture and/or perineal fistulae were seen at the Special Treatment Clinic, University College Hospital, Ibadan. Twelve of the patients came from villages around Ibadan and they 
were referred to us by the private medical practitioners whom they had first consulted for further treatment after the failure of 'native' medicine. The remaining patients reported directly at the General Out-Patient Department of the Hospital and were then referred to our Clinic. It must be pointed out that these patients by no means formed the total number of such cases seen in this hospital as others were seen at the Urology Clinic.

A detailed history of the onset of symptoms and the progress until the complications developed were taken from the patients. In particular, the interval between the first appearance of urethral discharge and the development of symptoms suggesting urethral stricture was noted. Enquiries were made into the type(s) of treatment received before reporting to our Clinic.

The clinical findings for each patient were recorded, noting urethral discharge, periurethral abscess, penile ulcers, palpable urethral stricture, perineal fistulae, inguinal swellings, and prostatic enlargement. Bacteriological examinations of specimens obtained from the discharges from the urethra and the fistulae were carried out. Each patient had a urine examination, Venereal Diseases Research Laboratory (VDRL) test, urethrogram, and blood urea estimation. Intravenous pyelogram (IVP) was performed when indicated to exclude renal damage. Frei's test and the lymphogranuloma venereum complement fixation test were carried out in all cases.

\section{Results}

The clinical features of the sixteen patients reported are summarized in the Table. Twelve patients were above 50 years of age. The youngest patient was an unmarried 25 year-old man (Case 1); he had had chronic gonorrhoea for 4 years and had received treatment from many herbalists without cure. $\mathrm{He}$ decided to seek proper medical treatment because he wanted to get married. When he was first seen in the Clinic, he could only pass urine through the scrotal fistulae (Fig. 1); the meatus and part of the anterior urethra was blocked by a stricture.
Fifteen of the sixteen patients had gonococcal urethral stricture and the one remaining patient had gonococcal prostatitis. Nine (60 per cent.) of the patients had already developed perineal/scrotal fistulae (watering-can perineum) by the time they

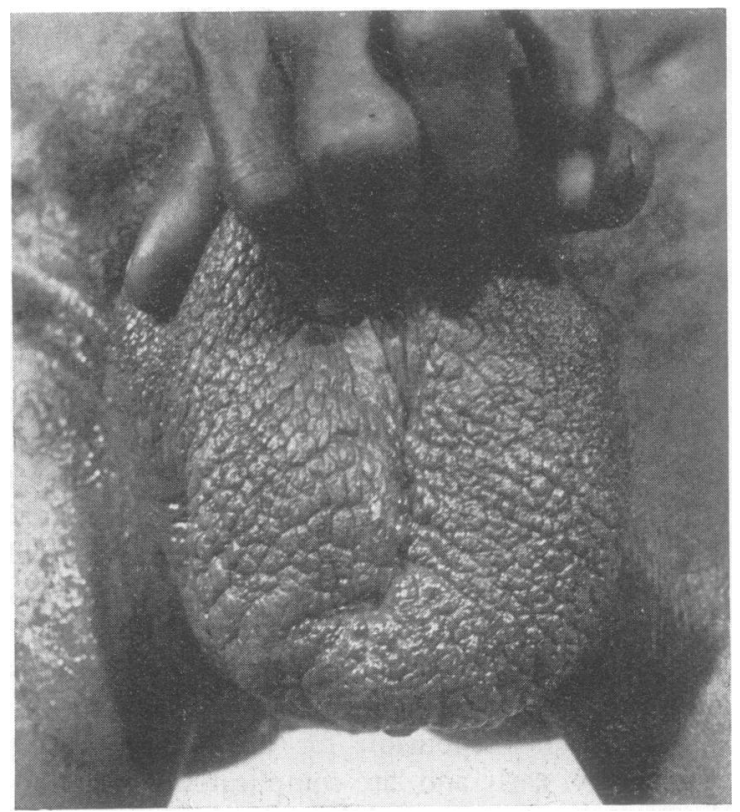

FIG. 1 Case 1. Oedematous scrotum and wateringcan scrotum. Note multiple fistulae

were first seen in the Hospital. One patient (Case 13) with urethral stricture also developed an inguinal hernia, which probably resulted from continuous straining during micturition.

TABLE Clinical features of sixteen patients with gonococcal urethral stricture and/or watering-can perineum

\begin{tabular}{|c|c|c|c|c|c|}
\hline $\begin{array}{l}\text { Case } \\
\text { no. }\end{array}$ & $\begin{array}{l}\text { Age } \\
\text { (yrs) }\end{array}$ & $\begin{array}{l}\text { Presenting } \\
\text { symptoms }\end{array}$ & $\begin{array}{l}\text { Relevant past medical } \\
\text { history }\end{array}$ & Clinical diagnosis & $\begin{array}{l}\text { Laboratory and radiological } \\
\text { results }\end{array}$ \\
\hline 1 & 25 & $\begin{array}{l}\text { Scrotal and penile swelling } \\
\text { Passing urine through many } \\
\text { openings in perineum } \\
\text { Fever }\end{array}$ & $\begin{array}{l}\text { Gonorrhoea } 4 \text { years } \\
\text { ago } \\
\text { Unmarried }\end{array}$ & $\begin{array}{l}\text { Urethral stricture and } \\
\text { watering-can scrotum }\end{array}$ & $\begin{array}{l}\text { (a) Pus from perineal fistulae grew } \\
\text { gonococci } \\
\text { (b) VDRL test negative } \\
\text { (c) Urethrogram revealed a } \\
\text { stricture (Fig. 1) }\end{array}$ \\
\hline 2 & 45 & $\begin{array}{l}\text { Straining during micturition } \\
\text { Dysuria } \\
\text { Mutiple fistulae in scrotum }\end{array}$ & $\begin{array}{l}\text { Gonorrhoea } 10 \text { years } \\
\text { ago } \\
\text { Married }\end{array}$ & $\begin{array}{l}\text { Urethral stricture and } \\
\text { watering-can scrotum }\end{array}$ & $\begin{array}{l}\text { (a) Urethral swab and swab from } \\
\text { scrotal fistula grew gonococci } \\
\text { (b) Urine grew } E \text {. coli } \\
\text { (c) VDRL test negative } \\
\text { (d) Urethrogram revealed stricture } \\
\text { at middle of penile urethra } \\
\text { (Fig. 2) }\end{array}$ \\
\hline 3 & 45 & $\begin{array}{l}\text { Intermittent discharging sinuses } \\
\text { in the perineum } \\
\text { Straining during micturition } \\
\text { Dysuria }\end{array}$ & $\begin{array}{l}\text { Gonorrhoea more than } \\
10 \text { years ago } \\
\text { Previous history of } \\
\text { urinary retention } \\
\text { Divorced }\end{array}$ & $\begin{array}{l}\text { Watering-can perineum } \\
\text { Prostatic abscess }\end{array}$ & $\begin{array}{l}\text { (a) Prostatic fluid grew gonococci } \\
\text { (b) Urine and scrotal swab grew } \\
E \text {. coli } \\
\text { (c) VDRL test negative } \\
\text { (d) Urethrogram revealed sinus } \\
\text { from proximal third of penile } \\
\text { urethra into scrotum (Fig. } 3 \text { ) }\end{array}$ \\
\hline
\end{tabular}




\begin{tabular}{lll}
$\begin{array}{l}\text { Case } \\
\text { no. }\end{array}$ & $\begin{array}{l}\text { Age } \\
\text { (yrs) }\end{array}$ & $\begin{array}{l}\text { Presenting } \\
\text { symptoms }\end{array}$ \\
\cline { 1 - 3 } & $\begin{array}{l}\text { Straining during micturition } \\
\text { Dysuria } \\
\text { Postmicturition } \\
\text { Dribbling }\end{array}$ \\
\hline 54 & $\begin{array}{l}\text { Straining during micturition } \\
\text { Scrotal swelling } \\
\text { Passing urine through many } \\
\text { fistulae in scrotum } \\
\text { Suprapubic swelling }\end{array}$ \\
\hline 6 & $\begin{array}{l}\text { Swelling of scrotum and penis } \\
\text { Passing urine through many } \\
\text { fistulae in scrotum and perineum }\end{array}$ \\
\hline 56 &
\end{tabular}

\begin{tabular}{lll}
\hline 7 & 60 & $\begin{array}{l}\text { Passing urine 'in a spray' out of } \\
\text { many holes at tip of penis } \\
\text { Dysuria } \\
\text { Penile and scrotal swelling } \\
\text { Purulent discharge from penile } \\
\text { fistulae }\end{array}$ \\
\hline 8 & $\begin{array}{l}\text { Chronic urethral discharge (2 yrs) } \\
\text { Holes in perineum }\end{array}$
\end{tabular}

\begin{tabular}{lll}
\hline 9 & 60 & $\begin{array}{l}\text { Straining during micturition } \\
\text { Dysuria } \\
\text { Purulent offensive urethral } \\
\text { discharge }\end{array}$ \\
\hline 11 & $\frac{\text { Straining during micturition }}{62}$ & $\begin{array}{l}\text { Straining during micturition } \\
\text { Scrotal swelling } \\
\text { Chronic urethral discharge } \\
\text { Penile fistulae }\end{array}$ \\
\hline 12 & $\begin{array}{l}\text { Poor urinary stream } \\
\text { Dysuria } \\
\text { Purulent urethral discharge }\end{array}$
\end{tabular}

\begin{tabular}{|c|c|c|}
\hline 13 & 68 & $\begin{array}{l}\text { Urethral discharge and dysuria } \\
\text { for } 10 \text { years } \\
\text { Straining during micturition } \\
\text { Right inguinal swelling for } 4 \text { yrs }\end{array}$ \\
\hline 14 & 72 & $\begin{array}{l}\text { Straining during micturition } \\
\text { Poor urinary stream }\end{array}$ \\
\hline 15 & 80 & $\begin{array}{l}\text { Urethral discharge and dysuria } \\
\text { for } 3 \text { years } \\
\text { Swollen penis with fistulae }\end{array}$ \\
\hline 16 & 31 & $\begin{array}{l}\text { Urethral discharge, dysuria, and } \\
\text { low backache for } 6 \text { months }\end{array}$ \\
\hline
\end{tabular}

Relevant past medical history

Gonorrhoea more than 25 years ago

Married twice without

children

Second wife had two

children by another man

Gonorrhoea 20 years ago

Married

Gonorrhoea 6 years ago Married
Clinical diagnosis

Chronic gonorrhoea with stricture

Right testicular atrophy

Urethral Stricture Watering-can scrotum with chronic urinary retention Left epididymoorchititis

\section{Urethral stricutre} Watering-can scrotum Periurethral abscess (saxophone penis) Extravasation of urine into scrotum

Chronic urethral discharge for 15 years Wife left him because of his illness

Gonorrhoea 20 years ago

Separated from wife Gonorrhoea over
30 years ago

Gonorrhoea 8 years ago

Married

\section{Gonorrhoea over}

5 years ago

Previous history of

urinary retention

Divorced

Gonorrhcea 30 years
ago
Separated from wife

Separated from wife

Gonorrhoea 10 years
ago
Married

\section{Gonorrhoea 20 years}

ago

Married with children

Gonorrhoea on four previous occasions

First infection over 50 year ago

Gonorrhoea 6 months ago

Right inguinal hernia

for 3 months

Urethral stricture Watering-can penis of

Urethral stricture

Watering-can scrotum

Urethral stricture

Urethral stricture

Urethral stricture

Watering-can penis

Urethral stricture

Urethral stricture

Right inguinal hernia

\section{Urethral stricture}

Bilateral testicular

atrophy

\section{Urethral stricture}

Saxophone penis

Watering-can perineum

Urethral stricture

Right inguinal hernia
Laboratory and radiological results

Urethral swab grew gonococci VDRL test negative

Urethrogram revealed several irregular strictures

Urine culture grew $E$. coli and Ps. aeruginosa

VDRL test negative

Urethrogram revealed two strictures, two fistulae, and prostatic abscess (Figs 4 and 5)

Urine culture grew $E$. coli, Ps. aeruginosa, and Strep. faecalis VDRL test negative

Urethrogram revealed sinus tracts leading from urethra into scrotum and complete block in posterior urethra (Fig. 6)

Urine culture grew E. coli, Proteus

sp., and Citrobacter sp.

Urethral swab grew $E$. coli

VDRL test negative

Urethrogram revealed stricture

Urine and urethral swab grew

E. coli

VDRL test negative

Urethrogram revealed stricture (Fig. 7)

VDRL test negative

Urethrogram-defaulted

VDRL test negative

Urethrogram revealed stricture

Urine culture grew $E$. coli

Urethral swab culture grew

gonococci, E. coli, and Proteus spp.

VDRL test positive (titre 1:4)

Urethrogram-patient defaulted

Urethral swab grew gonococci and

Trichomonas vaginalis

VDRL test negative

Urethrogram revealed long irregular stricture

Urethral swab grew gonococci

VDRL test positive (titre 1:2)

Urethrogram - patient defaulted

VDRL test negative

Urethrogram-patient defaulted

Urethral fistulae grew gonococci

Urine culture grew $E$. coli

VDRL test negative

Urethrogram revealed stricture

Gonococci isolated from urethral swab

VDRL test negative

Urethrogram multiple strictures and periurethral abscesses (Fig. 8) 
The interval between the time when the patient first contracted gonorrhoea and the development of complications ranged from 4 to 50 yrs. Enquiries into the marital status of the fifteen patients revealed that one was unmarried, eight were living with their wives (including three polygamous men), two were divorced, and four were separated from their wives for reasons not unconnected with their illnesses. One patient (Case 4) was infertile, probably because of the long-standing gonococcal infection.

Neisseria gonorrhoeae was isolated from the urethral or perineal discharges of only eight patients, including one case of gonococcal prostatitis. Five of the sexual partners of the patients were also positive for gonococci. Escherichia coli was the other organism commonly isolated from patients' urine or urethral/ perineal discharges. In two patients (Cases 11 and 13) the VDRL test was positive in low titres. None gave a history suggestive of syphilis, but these two patients and their contacts were given appropriate treatment for treponemal infection, after which the VDRL test became negative, but childhood yaws could not be excluded.

Fig. 2 shows the urethrogram of Case 2, with stricture at the mid-penile urethra. Fig. 3 shows the positions of the perineal fistulae in Case 3. Figs 4 and 5 demonstrate the watering-can perineum with fistulae of the perineum and scrotum (Case 5). Fig. 5 shows distorted penis due to periurethral abscess (saxophone penis) of Case 6 . One patient had hydronephrosis and hydroureter from chronic urethral stricture. Figs 7 and 8 show urethral strictures with periurethral abscesses.

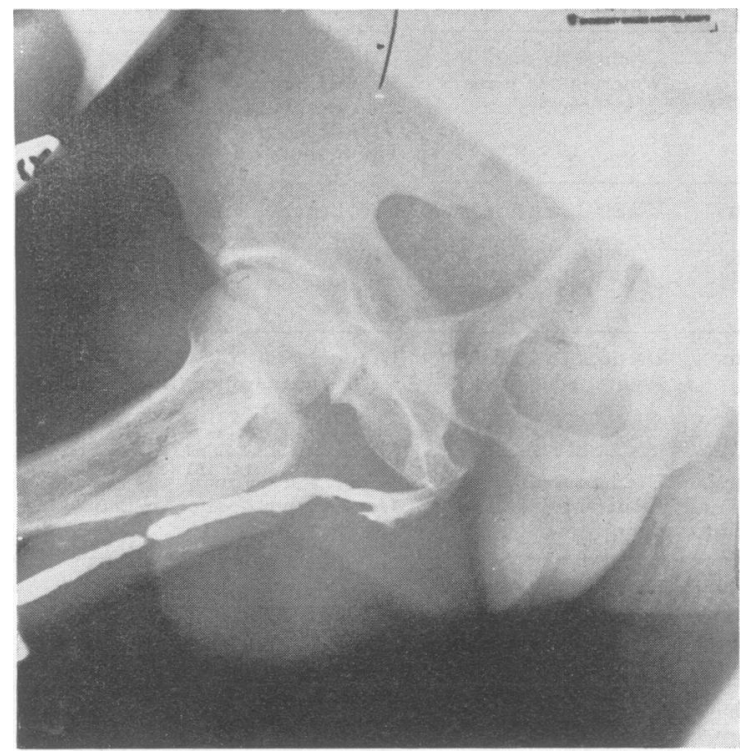

FIG. 2 Case 2. Stricture at mid-penile urethra with extravasation at bulbous portion

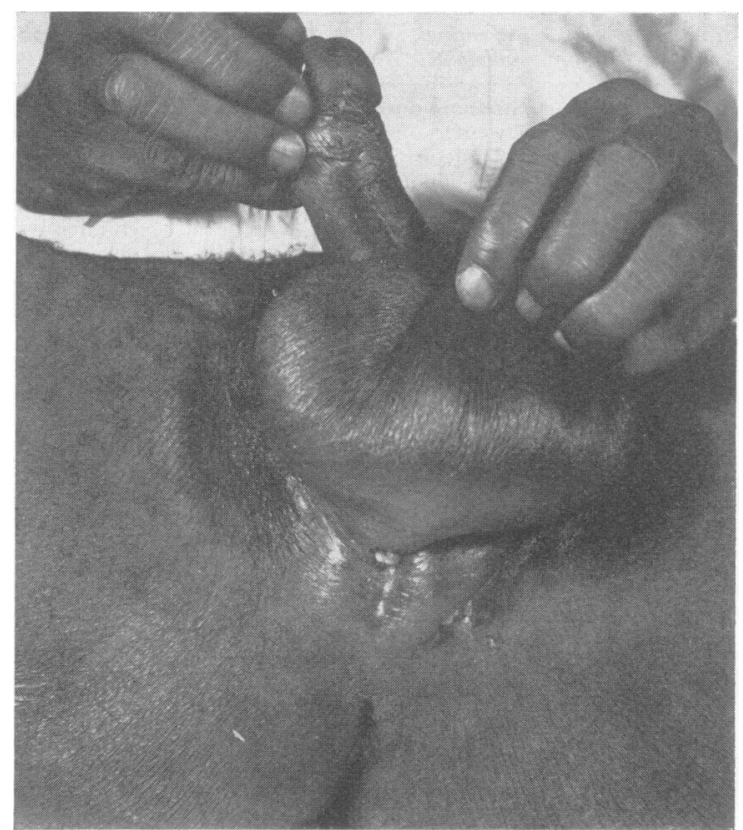

FIG. 3 Case 3. Watering-can perineum with multiple fistulae

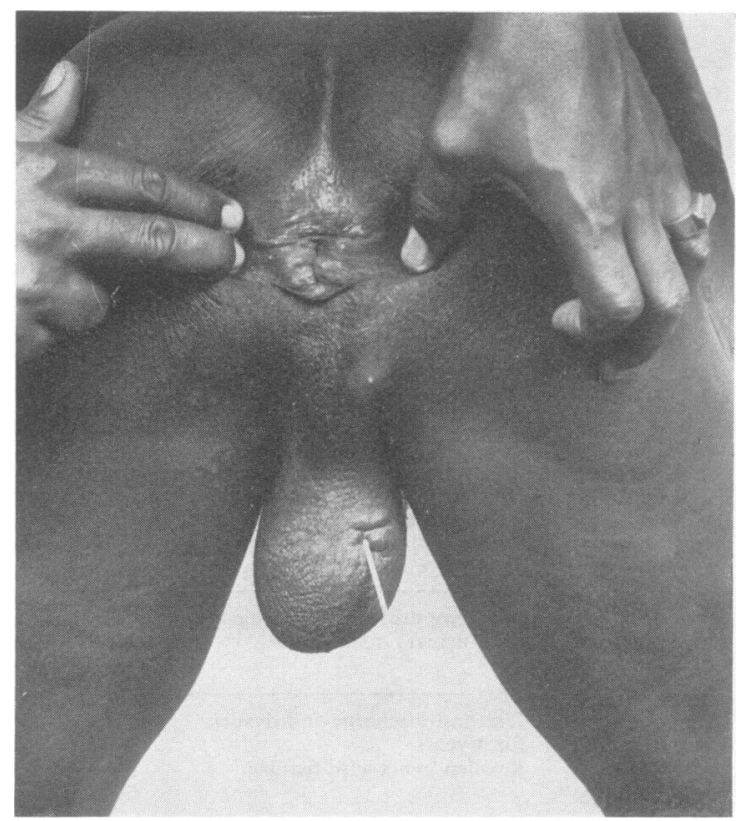

FIG. 4 Case 5. Watering-can scrotum. Fistulae on perineum and scrotum. $A$ probe is inserted into one of the fistulae. Note haemorrhoids due to constant straining 


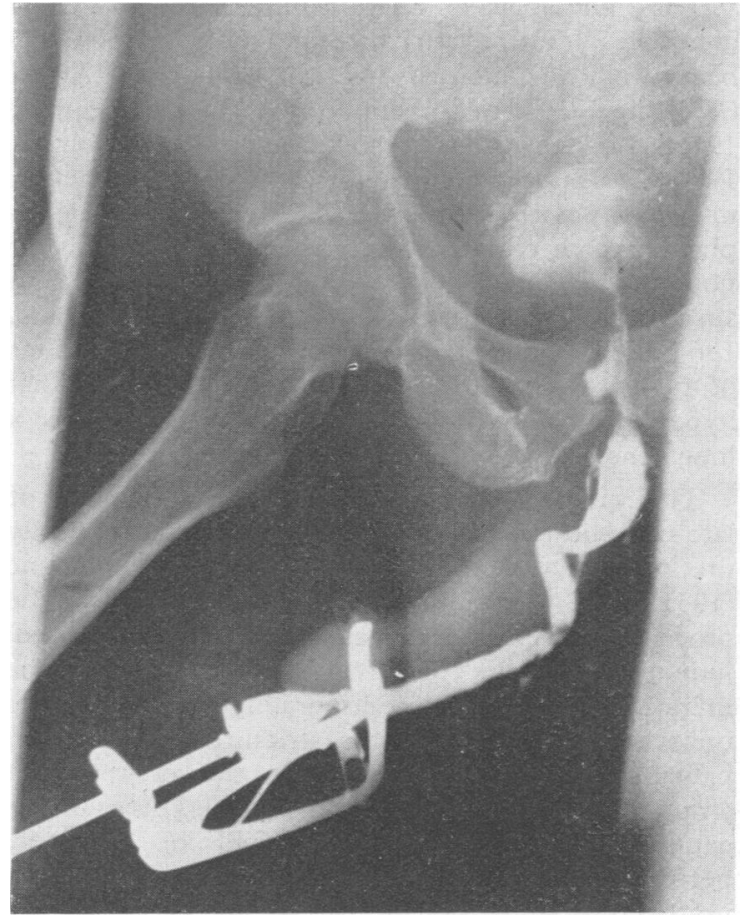

FIG. 5 Case 5. Urethrogram showing two strictures, two fistulae outlined by the contrast, and prostatic abcesss

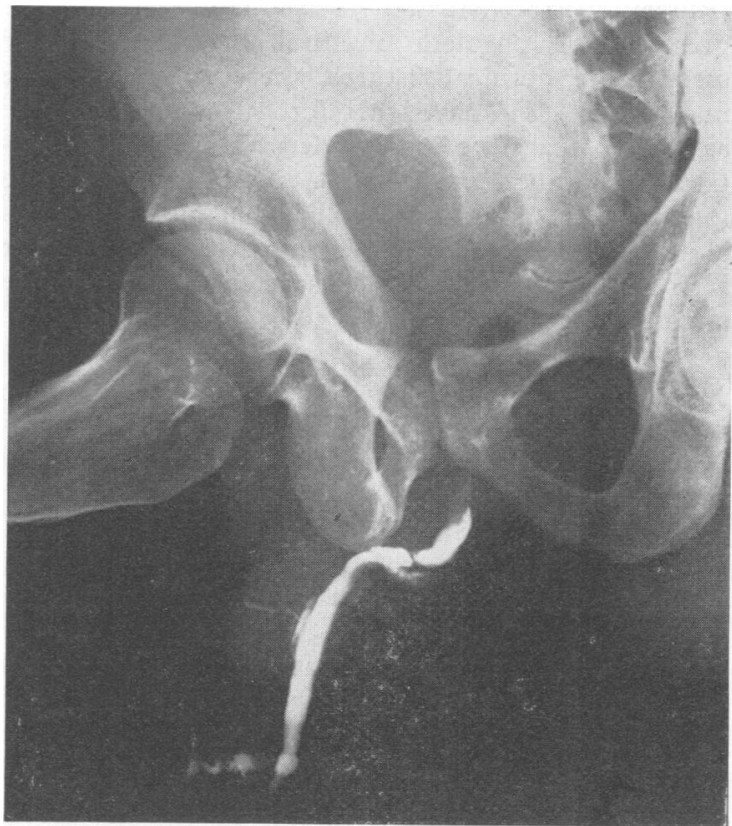

FIG. 7 Case 8. Urethral stricture with periurethral abscess and perineal fistulae

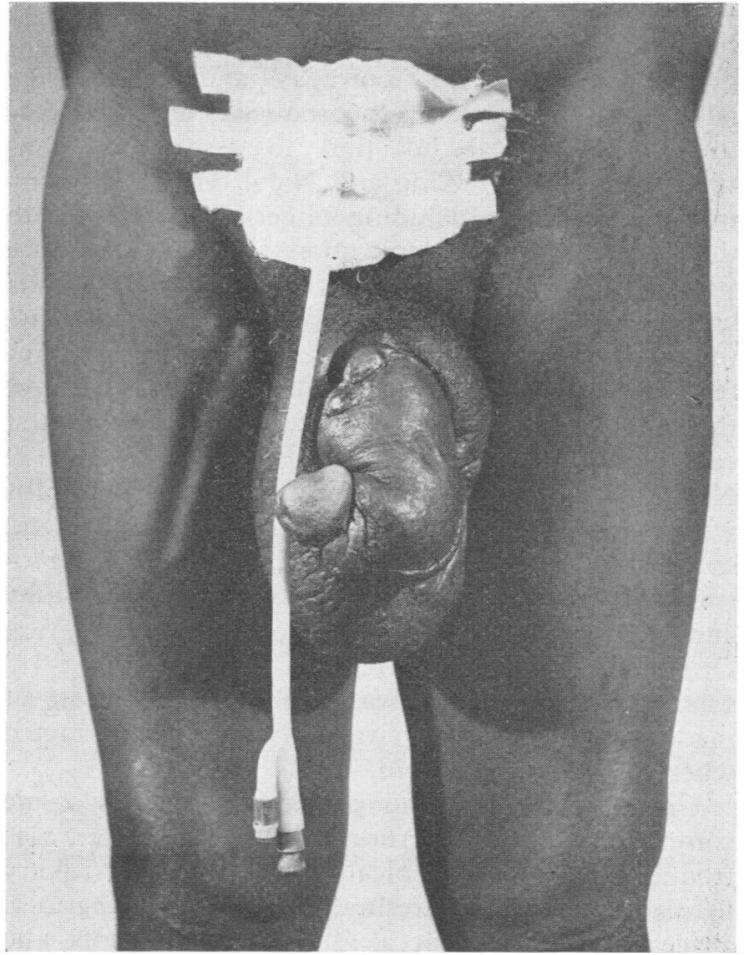

FI G. 6 Case 6. Distorted penis due to periurethral abscess (saxophone penis) with oedematous scrotum. Suprapubic catheter inserted because of acute urinary retention

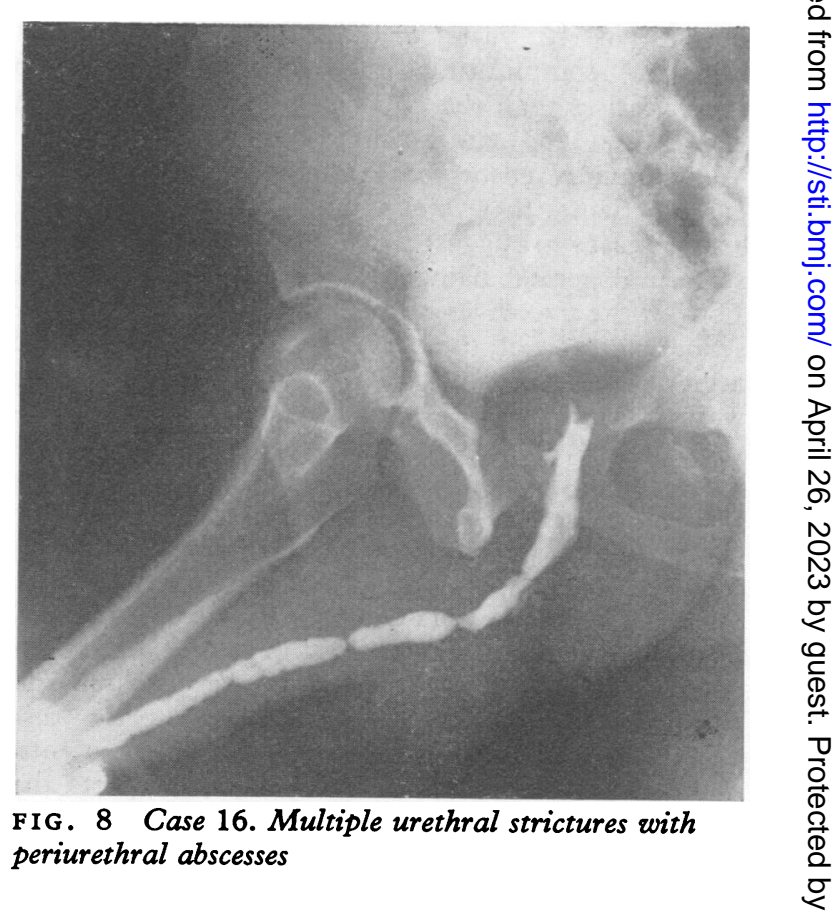




\section{Discussion}

In Europe and North America true chronic gonorrhoea probably does not exist nowadays and the tendency is to attribute most of the sequelae of adequately treated gonococcal infection to associated 'nonspecific urethritis' (King and Nicol, 1969). In many tropical countries including Nigeria, however, both the early and late complications of gonorrhoea are still frequently seen, because the majority of patients with venereal diseases receive either inadequate treatment or none or else they have repeated infections after receiving adequate treatment, since their consorts are rarely treated. The commonest early complications of gonorrhoea encountered in Nigeria are epididymitis and epididymo-orchitis which may develop into testicular atrophy and consequently result in either oligospermia or azoospermia. There were two cases of testicular atrophy and one of epididymo-orchitis in the present series. One of the patients with testicular atrophy (Case 14) was infertile and this was probably the result of inadequately treated gonorrhoea which he contracted when he was 28 years old.

Urethral stricture and perineal fistulae as a late complication of gonorrhoea in the male are also frequently seen in tropical countries. The urinary fistulae follow periurethral, scrotal, or perineal abscess due to gonococcal infection in patients who have already developed urethral stricture distal to the sites of the abscess formation. The latent period between the original attack of gonorrhoea and the development of these late sequelae varied from 4 to 50 years in the present series. Six patients had latent periods of 10 years or less. Therefore urethral stricture complicating gonorrhoea may develop much earlier than the 20 years previously suggested by Mayne (1955) and Griffith (1963).

Although $N$. gonorrhoeae could be isolated from only eight patients, there was enough evidence in all the sixteen cases to suggest that the primary cause of the structural genital damage was gonococcal infection. Four of the five wives of the married patients and the sexual partner of the only unmarried patient had asymptomatic gonococcal infections, two of the women were married to patients whose discharges were negative for gonococci. The reason for this finding may be that the majority of these patients had taken some antimicrobial agents, tetracycline capsules and penicillin injections being the commonest (Alausa and others, 1975), before they were referred to the hospital, while the wives or sexual partners of these patients did not receive similar chemotherapy. The high isolation rate of $E$. coli and other resistant Gram-negative bacilli in the discharges and urinary cultures of many patients, included those negative for gonococci, supports the hypothesis that urethral stricture produces urinary infection (Elebute, 1966; Hutt and Sood, 1963).
The aetiological relationship between postgonococcal urethral stricture and hypertension has been well documented in East and West Africa (Williams, 1944; Somers, 1960, 1964; Leather, 1961; Tulloch, Wilson, and King, 1964; Elebute, 1966). It has been suggested that ascending infection in patients with stricture leads to chronic pyelonephritis which either causes hypertension directly or potentiates the development of hypertension in susceptible individuals (Elebute, 1966; Somers, 1964). Our experience has confirmed the observations of these previous authors. It is therefore important that hypertension in these patients be followed up for a long time after the stricture has been treated.

The value of urethrography in the diagnosis of late complications of gonococcal infection, especially urethral stricture, has been stressed by Loughnane (1941) and Mayne (1955, 1956). Nevertheless, the procedure does not appear to be widely used, judging from the few reports published in the literature. However, urethrography has helped to uncover cases in which the stricture has not been palpable as well as confirming the existence of strictures in twelve of the cases reported here. In our experience, this procedure should be routinely performed on patients giving a long history of urethritis in the tropics.

Urethral dilatation and/or internal urethrotomy and, in the more serious cases, external urethrotomy or excision of the stricture are regarded as the treatment of choice in most cases of stricture (Russell, 1915; Mayne, 1955). However, in the presence of purulent urethral discharge and/or discharging perineal fistulae, these procedures are inadvisable. We have therefore used conservative antibiotic treatment and avoided surgical instrumentation as much as possible. Our patients were managed by giving tetracycline $500 \mathrm{mg}$. four times a day or ampicillin $500 \mathrm{mg}$. three times a day for 2 to 6 weeks, until the discharge from the urethrae and fistulae ceases.

If there is penile pain, dysuria, and frequency, Mist. Pot. Cit et Hyoscyamus $0.5 \mathrm{oz}$ or Pyridium tablets three times a day was added to the prescription. To hasten resolution of the damage to the tissues and the penetration of the antibiotics to the inflamed areas, Ambezim (Ormonoterapia Richter, Italy) or Chymoral tablets (Armour Pharm. Co.) were prescribed at two tablets three times a day with the antibiotics. This regime was successful in the initial treatment of all the patients reported except one who developed acute retention and required suprapubic cystotomy. The urine was examined for pathogens at every visit and the antibiotics altered according to the antibiogram when necessary.

When there was no discharge and the fistulae had healed, patients with poor stream and severe straining 
at micturition were referred to the urologist for urethral dilatation and surgical management.

It is important to point out that the surgical treatment of a stricture is not curative and that prognosis is poor. The patient requires regular dilatation to prevent recurrence of stenosis. It is easier and cheaper to prevent the development of the stricture by early diagnosis and adequate treatment of the acute gonococcal urethritis, than to treat such late complications as stricture and wateringcan perineum.

With the high and rising incidence of gonococcal infection in many countries of tropical Africa, it is probable that many more patients will develop these complications unless the present standards of health care delivery and health education are improved, particularly for sexually transmitted diseases, to ensure that more patients receive proper and adequate treatment. To achieve these objectives, more centres for diagnosis, treatment, and contact tracing need to be established.

\section{References}

Alausa, O., Osoba, A. O., and Sogbetun, A. O. (1975) $\mathcal{F}$. med. pharm. Marketing, 1, 8
Elebute, E. A. (1966) Trans. roy. Soc. trop. Med. Hyg., 60,676

Grifrith, J. (1963) Eugen. Rev., 55, 103

GutHe, T. and IDsøE, O. (1968) Brit. f. vener. Dis., 44, 35

- (1972) Postgrad. Med. F., 48, Suppl. 1, p.7

HutT, M. S., and Sood, N. K. (1963) E. Afr. med. F., 40, 202

KING, A., and Nicol, C. (1969) In 'Venereal Diseases', 2nd ed., p.166. Baillière, Tindall, and Cassell, London

LEATHER, H. M. (1961) Trans. roy. Soc. trop. Med. Hyg., 55,89

Loughnane, F. M. (1941) Brit. F. Urol., 13, 199

MAYNE, G. O. (1955) Brit. F. vener. Dis., 31, 98 (1956) Ibid., 32, 119

Osoba, A. O. (1972) Ibid., 48, 116 , OnIpade, A., and Alausa, K. O. (1975) Nig. med. f., 5, 401

Russel.., R. H. (1915) Brit. F. Surg., 2, 375

SOMERS, K. (1960) f. trop. Med. Hyg., 63, 260 (1964) Brit. F. vener. Dis., 40, 194

Tulloch, J. A., Wilson, A. M. M., and King, M. H. (1964) E. Afr. med. F., 41, 356

W.H.O. (1974) W.H.O. Chron., 28, 314

Willcox, R. R. (1972) Brit. f. vener. Dis., 48, 163

WILliams, A. W. (1944) E. Afr. med. F., 21, 328 